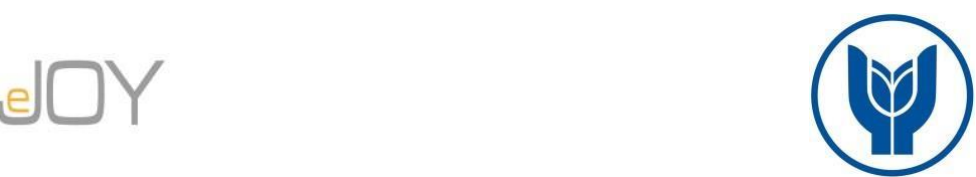

Kara, E., Dalgın, T., Çeken, H. / Journal of Yasar University, 2021, 16/63, 1318-1337

\title{
Ordu Çambaşı Kayak Merkezindeki Kış Turizmi Faaliyetlerinin Yerel Kalkınmaya Etkisi ${ }^{1}$
}

\section{The Effect of Winter Tourism Activities in the Ordu Çambaşı Ski Center on Local Development}

\author{
Emrah KARA, Muğla Sitkı Koçman Üniversitesi, Türkiye, emrahkara9552@hotmail.com \\ Orcid No: 0000-0002-3363-8399 \\ Taner DALGIN, Muğla Sıtkı Koçman Üniversitesi, Türkiye, tanerdalgin@mu.edu.tr \\ Orcid No: 0000-0002-7645-1989 \\ Hüseyin ÇEKEN, Muğla Sıtkı Koçman Üniversitesi, Türkiye, hceken@mu.edu.tr \\ Orcid No: 0000-0002-6614-3018
}

\begin{abstract}
Öz: Tüm turizm türleri içerisinde daha fazla gelire sahip olma ve turizm etkinliklerinin tüm yıla yayılmasına yardımcı olma özellikleri ile kış turizmi ulusal ve bölgesel turizm politikaları içerisinde önemli yer tutan bir turizm türüdür. Türkiye, Uludăg, Palandöken, Kartalkaya, Erciyes ve Ilgaz gibi önemli klş turizmi merkezlerine sahiptir. Ayrıca, yerel olarak faaliyet gösteren kış turizmi merkezlerinin sayısı da azımsanmayacak miktardadır. Bu yerel kış turizmi merkezlerinden bir tanesi de Ordu ilinde bulunmaktadır. 2017 yılında faaliyete giren Çambaşı Kayak Merkezi ziyaretçilerini en iyi şekilde ağırlamaya başlamıştır. Ordu ili kış turizmi açısından önemli bir potansiyel taşımakla birlikte, ulusal ve uluslararası anlamda henüz yeterince bilinirliğe sahip değildir. Bu çalışmanın amacı, kış turizminin Ordu iline yapmış olduğu katkıların yerel kalkınmayı nasıl etkilediğini incelemektir. Ordu ilinin Çambaşı yöresindeki kış turizminin yerel kalkınma açısından önemini ortaya koymak amacılla, yerel yönetim temsilcilerinden, Ordu Üniversitesinde görev yapan turizm alanındaki akademik personelden, esnaf ve zanaatkârlardan, turizm işletmeleri ve kış turizmi merkezi çalışanlarından mülakat formu yardımıyla veri toplanmıştır. Araştırmada elde edilen bulgular genel olarak değerlendirildiğinde, Ordu ilinin kış turizmi açısından önemli çekiciliklere sahip olmakla birlikte, henüz bir kış turizmi merkezi olarak özellikle uluslararası anlamda yeterince bilinirliğe sahip olmadığı görülmektedir. Bölgede kış turizmi aktivitelerinin gerçek anlamda kalkınmaya katkı sağlaması, bölgeyi daha çok ziyaretçinin tercih etmesiyle mümkün olacaktır. Klş turizmine yönelik bölgeye olan talebin artması ise ancak etkili ve verimli pazarlama çalışmalarıla mümkün olacaktır. Bu bağlamda Ordu ilinin kış turizminden daha fazla pay alabilmesi ve çekicilik yaratması için araştırmada çeşitli öneriler geliştirilmiştir.
\end{abstract}

Anahtar Kelimeler: Kış Turizmi, Çambaşı Kayak Merkezi, Bölgesel Kalkınma

JEL Sinıflandırması: R11, Q26, Q31

Abstract: Winter tourism is a type of tourism that has an important place in national and regional tourism policies due to its characteristics such as higher income compared to other tourism types and contributing to the spread of the tourism season throughout the year. Turkey has the important winter tourism centers such as Uludag, Palandöken, Kartalkaya, Erciyes and Ilgaz. In addition, the number of winter tourism centers operating locally is substantial. One of these local winter tourism centers is located in Ordu province. One of these local winter tourism centers is located in Ordu province. Çambassl Ski Center, which was opened in 2017, started to host its visitors in the best way. Although Ordu province has an important potential in terms of winter tourism, it does not have enough national and international recognition yet. The aim of this study is to examine how the contributions of winter tourism to Ordu region effect local development. In order to reveal the importance of winter tourism in the Ordu region in terms of local development, data were collected from local authority representatives, university academic staff in the field of tourism, tradesmen and craftsmen, tourism enterprises and winter tourism center employees with the help of an interview form. When the findings obtained in the study are evaluated in general, it is seen that Ordu province has important attractions in terms of winter tourism, but it is not yet well known as a winter tourism destination, especially internationally. The real contribution of winter tourism activities to the

\footnotetext{
${ }^{1}$ Bu araştırma, Emrah Kara'nın Haziran 2020'de yayınlanan " Kış Turizminin Yerel Kalkınmaya Etkisi: Ordu İli Örneği " isimli Yüksek Lisans tezinden yararlanılarak hazırlanmıştır.
} 
development in the region will be possible if more visitors prefer the region. Increasing the demand for winter tourism in the region will only be possible with effective and efficient marketing efforts. In this context, various suggestions have been developed in the study in order for Ordu to get a higher share from winter tourism and create an attraction.

Keywords: Winter Tourism, Çambaşı Ski Center, Regional Development

JEL Classification: R11, Q26, Q31

\section{Giriş}

Bireylerin turistik ürün algılamaları ve istekleri, bütün sektörlerde olduğu gibi değişen koşullara uygun olarak sürekli değişim göstermektedir. Alternatif turizm, içinde bulunduğumuz dönemde kitle turizminden doğan tepkilerin bir sonucu olarak daha özgün turistik ihtiyaçlara sahip kitleler tarafından talep edilen butik niteliğe sahip turistik ürün ve hizmetleri ifade eden genel bir sınıflandırma olarak ön plana çıkmaktadır. Alternatif turizm denildiğinde, bu sınıflandırmanın kapsamına giren turizm türleri ve aktivitelerinin sınırlarını tam olarak belirlemek mümkün olmasa da, genel olarak aktif turistik taleplere cevap veren, çevreye saygıl1, sürdürülebilir ve kitlesel talep yerine, özgün bir motivasyona sahip sınırlı bir talebe hitap etmeyi amaçlayan bir turizm anlayışından bahsedilebilir. Kış turizmi, bu açıdan alternatif turizm türleri arasında yer almaktadır.

Kış turizmi turizm sektörü içerisinde ortalamanın üzerinde gelir yaratan bir alternatif turizm türü olarak dikkat çekmektedir. Kış turizmi, hem az gelişmiş hem de gelişmekte olan ülkelerin ekonomik kalkınması açısından büyük bir önem arz etmektedir. Türkiye Uludağ, Palandöken, Kartalkaya, Erciyes ve Ilgaz gibi önemli kış turizmi merkezlerine sahiptir. Ayrıca, bilinirliği yüksek bu kış turizmi merkezlerinin dışında yerel olarak faaliyet gösteren kış turizmi merkezleri de bulunmaktadır. Bu yerel kış turizmi merkezlerinden bir tanesi de Ordu ilinde bulunmaktadır. 2017 yılında faaliyete giren Çambaşı Kayak Merkezi ziyaretçilerini en iyi şekilde ağırlamaya başlamıştır. Ordu ili kış turizmi açısından önemli bir potansiyel taşımakla birlikte, ulusal ve uluslararası anlamda henüz yeterince bilinirliğe sahip değildir.

$\mathrm{Bu}$ çalışmanın amacı, kış turizminin yerel kalkınmaya yaptığı etkileri araştırmak ve Ordu ili özelinde yerel kalkınmada bir araç olarak kış turizmi potansiyelini belirlemektir. Ordu ilindeki kış turizminin yerel kalkınma açısından önemini ortaya koymak amacıyla, yerel yönetim temsilcileri, turizm alanındaki üniversite akademik personeli, esnaf ve zanaatkârlar, turizm işletmeleri ve kış turizmi merkezi çalışanlarından mülakat formu yardımıyla veri toplanmıştır. Araştırma kapsamında elde edilen verilerden yararlanılarak Ordu ilinin kış turizmi potansiyeli değerlendirilmiş ve potansiyelin geliştirilmesine yönelik öneriler geliştirilmeye çalışılmıştır. 


\section{Kavramsal Çerçeve}

Kış turizmi alternatif turizm türleri arasında yer alan ve turizm faaliyetlerini yılın tümüne yayılması için son dönemde üzerinde durulan ve önemli gelişmeler kaydeden bir turizm türüdür. Kış turizminin çoğunlukla gerçekleştirildiği dağlık alanlar güzel doğası ve temiz havası yaz aylarında da turizm hareketlerine süreklilik kazandırmaktadır. Kış döneminde kış turizmi etkinliklerine sahne olan bölgelerden, yaz aylarına gelindiğinde kırsal turizm, yayla turizmi, festival ve şenlikler, off-road yarışları vb. etkinlikleri gerçekleştirmek amacıyla yararlanılmaktadır. Bu şekilde kış turizmi destinasyonları, turizm faaliyetlerinin on iki aya yayılmasına imkân sunmaktadır (Ağger, 2011: 6).

Kış turizmi kavramıyla ilgili literatürde birçok tanımlamaya yer verilmektedir. Ülker (1992: 12) kış turizmini; "genellikle karlı ortamda yapılan ve kış sporları uygulamalarının ăgırlıklı olarak geliştirildiği merkez ve alanlar üzerinde yoğunlaşan bir turizm hareketi" olarak ifade etmektedir. İncekara (1998: 3)' ya göre kış turizmi; “odağında kayak sporunun bulunduğu ve buna uygun karlı ve ĕgimli alanlara yapılan seyahatleri, konaklama ve diğer hizmetlerden yararlanmayı kapsayan faaliyet ve ilişkilerin bütünüdür.” Doğaner (2001: 178)' e göre k1ş turizmi; "kar yă̆ışına bă̆lı bir şekilde dă̆ların kar alabilen yükselti kuşă̆ında ă̆ırlık kazanan bir turizm türüdür.,

Kış turizmi ekonomik ve toplumsal açıdan çeşitli faydalara sahiptir. Öncelikle kış turizmi, turistik faaliyetlerin tüm yıla yayılmasını kolaylaştırarak, ülke ekonomisi için turizm sektörünün sürekli bir gelir kaynağına dönüşmesine katkı sağlamaktadır. Ayrıca kış turizmi, kırsal kalkınmayı da tetikler niteliktedir (Lim, 1997: 836-848). Kış turizmi ekonomik yönden, kalkınmanın yeterli düzeyde olmadığı dağlık ve ormanlık alanların kalkınmasına yardımcı olmakla birlikte, kalkınma sürecine hız kazandırmaktadır (İbragimov, 2001: 38). Kış turizmi yazın turistik bölgelerde çalışan kalifiye personelin kışın işsiz kalmasını engellemekte ve yıl boyunca turizm sektöründe çalışmasına imkân oluşturmaktadır. Kırsal bölgelerde kış turizmi açısından yapılan yatırımlar, yeni iş sahalarının oluşmasını sağlamakta ve pek çok ekonomik faaliyetin gelişmesine yardımcı olmaktadır. Örneğin; inşaat, ulaşım vb. sektörleri olumlu yönde etkilemektedir (Şebin, 2009: 21). Kış turizminin sağladığı diğer ekonomik ve toplumsal faydalar arasında, kırsal bölgelerdeki göçü önleme, istihdam açısından talep yaratma, bölge halkına kazanç sağlama, mevsimsellik sorununun önüne geçme ve alt yapının iyileştirilmesine katkıda bulunma sayılabilir. Kış turizmine katılan ziyaretçiler kayak sporu ve diğer etkinlikleri gerçekleştirme yoluyla toplumsal olarak sosyalleşme sürecine girer ve deneyimleri aktarmada firsat yakalarlar. Farklı yerlerden ve farklı statülerden gelen insanların bir arada buluşmasına imkân tanıyan bu etkinlikler kültürel etkileşimi arttırmaktadır (Kılıçarslan, 2008). 
Kış turizmi bölgelerindeki karın yerde kalış süresi, sahip olduğu topografik yapı, güneşli gün sayısı ve ulaşılabilirlik kış turizminin temel bileşenleri arasında yer almaktadır (Koşan, 1996: 3-6). Bunun yanı sıra kış turizminin gerçekleştirildiği yörenin manzarası, florası, otantik ve kültürel değerleri ile sahip olduğu mekanik tesisler, yeme-içme imkânlarının fazlalığı ve eğlence mekânları ürünün çekiciliğini arttıran önemli faktörler olarak sayılabilir (İncekara, 1998: 3). Kış turizmi merkezinde yer alan bu imkânlar, hem yöre halkının hem de turistlerin istek ve beklentilerini karşılaması açısından turistik alt yapının odak noktasını oluşturmaktadır. Kış turizmi merkezlerinin uzun dönemde başarıyı sağlayabilmesi, destinasyonların rekabet edebilme gücüyle ilişkilidir (Kämpf ve Kaspar, 2005: 6). Kış turizmi merkezlerinin sahip olması gereken özelliklerin başında öncelikle kış sporlarının temeli olan kayak için karakteristik bir deneyim sunabilmesi gelmektedir. Kış turizmi merkezleri nitelikli konaklama, yeme-içme ve ulaşım imkanlarının yanı sıra, kayak eğitimi, kayak malzemeleri kiralama, alışveriş imkanları gibi yan hizmetleri de sunmalıdır. Ayrıca teleferik ve telesiyej gibi yolların ve mekanik tesislerin sayısı da kış turizmi merkezinin işlevselliği açısından önemlidir (Priporas vd., 2012).

Kış turizmi merkezlerinde gerçekleştirilebilecek etkinlikler; kış ve yaz dönemi etkinlikleri olmak üzere iki başlık altında toplanabilir. Kış turizmi merkezlerinin geniş ve açık alanlarda bulunuyor olması turizmi, on iki aya yayma açısından önemli bir avantaj sağlamaktadır (Demirhan, 1992: 26; Bürki vd., 2003). Kış turizmi merkezlerini sadece kış turizmi ile sınırlandırmayıp aynı zamanda yaz dönemi etkinlikleri ile de sürdürülebilirlik açısından desteklemek gerekir. Kış dönemi etkinlikleri; alp disiplini kayak, snowboard, helikopter kayağı, kar kıză̆1, kar motoru ve buz pateni olarak açıklanabilir (Atasoy ve Kuter, 2005: 18; Berberoğlu, 2012: 33). Yaz dönemi etkinliklerini ise golf, trekking, tırmanma ve dağ bisikleti olarak sıralayabilmemiz mümkündür.

Literatürde kış turizmini farklı boyutları ile ele alan farklı çalışmalara rastlamak mümkündür. Kış turizmi ile ilgili araştırmaların bir kısmı belirli bölgelerde kış turizmine yönelik girişimlerin başarılı olması için gerekli koşulların neler olduğu üzerine odaklanmıştır. Hudson vd., (2004) Kanada'daki kış turizmi merkezlerinin rekabetçi ve sürdürülebilir olabilmesi için gerekli koşulları araştırdığı çalışmada, kayak merkezi işletmecisi, destinasyon yönetim organizasyonu, konaklama işletmesi sahipleri, tur operatörleri ve diğer ticari işletmeler gibi paydaşların kış turizmi merkezinin gelişimi ile ilgili iyi bir planlama çalışması yapmasının önemi üzerinde durmuştur. Yılmaz, Başar ve Pabuççu (2015), çalışmasında kış turizmi açısından işletmelerin rekabet avantajı sağlamasında en çok etkisi olan pazarlama kaynağının müşteri ilişkileri kapasitesi olduğunu belirlemiştir. Buna ilaveten, rekabetçi pazarlama strateji 
uygulamalarının, farklılaşma stratejisi ile gerçekleşebileceği de araştırmanın bir diğer önemli sonucu olarak bulunmuştur. Evren ve Kozak (2018), farklı kış turizmi merkezlerinin ön plana çıkan özelliklerini araştırdığı çalışmasında, Erciyes'in makul fiyatlar ve pist yoğunluğunun azlığı ile; Kartalkaya'nın turizm üst yapısının oluşturduğu kalite ile; Kartepe'nin ulaşım kolaylığı ile; Palandöken' in kar kalitesi ve liftleri ile; Uludağ'ın turizm üst yapısının meydana getirdiği çeşitlilik ile, ziyaretçilerin zihninde yer edindiğini tespit etmiştir. Türkeri (2014), yaptığı araştırmada Palandöken Kayak Merkezinin destinasyon kişiliğinin ölçülmesi neticesinde destinasyona atfedilen kişilik özelliklerinin dört grupta toplandığı ve bunların canlılık, yetkinlik-modern, samimiyet ve entelektüellik olduğu sonucuna ulaşmıştır. Hallman vd., (2015) Oberstdorf (Almanya) and Saalbach-Hinterglemm (Avusturya) kış turizmi merkezlerini tercih eden turistlerden veri topladıkları araştırmada kış turizmi merkezlerinin önemli sportif özelliklerinin bir birleşimi olan destinasyon imajının destinasyonu yeniden ziyaret etme niyetini etkilediği sonucuna ulaşmıştır.

Kış turizmi ile ilgili literatürdeki araştırmaların odaklandığı bir başka konu ise belirli ülkelerde veya bölgelerde kış turizminin gelişimi ile ilgili süreçlerdir. Cernaianu ve Sobry (2017), yaptıkları araştırmada Romanya'da kış turizminin gelişimini ele almıştır. Gonseth ve Vielle (2018), yaptıkları araştırmada kış turizminin İsviçre'de gelişimini ve durumunu ele almıştır. Uluslararası kayak destinasyonları İsviçre açısından önemli bir ekonomik etkiye sahiptir. Akkuş (2019), yaptığı araştırma da; Ilgaz Dağı'nın kış turizmi yönünden son yıllarda artan bir ivme kazandığı ve buna karşın 2015-2016 yıllarından sonra gerileme yaşadığı sonucuna varmıştır.

Kış turizmini konu alan çalışmaların üzerinde durduğu bir diğer konu kış turizmi faaliyetlerinin ekonomik kalkınmaya olan etkileridir. Çakmak ve Yılmaz (2018), çalışmasında; yaz aylarına nazaran kış dönemi boyunca misafir edilen turist sayısının turizm gelirlerine oransal etkisinin daha fazla olduğunu saptamıştır. Turizm gelirlerini kış turizmi perspektifinde daha fazla nasıl arttırılabileceği yönünde fikirler önermiştir. Bu araştırma amacı bakımından Çakmak ve Yılmaz'ın (2018) çalışmasına benzerlik göstermekle birlikte, Ordu ili özelinde kış turizmi potansiyelini belirlemeyi ve bölgesel kalkınmaya yönelik etkilerini değerlendirmeyi amaçlamaktadır.

\section{Ordu İlinin Kış Turizmindeki Potansiyeli}

Ordu'nun gerek yayla turizmi gerekse kış turizmi açısından önemli bir değeri olan Çambaşı Yaylası ve Çambaşı Kayak Merkezi her geçen gün turistik çekiciliğini arttırmaktadır. Şehrin ekonomik kalkınmasına yardımcı olmak ve kış turizmine ilgisini arttırmak amacıyla 2010 
yılında Çambaşı Kayak Merkezi yapım çalışmalarına başlanmıştır. Tesis alanında ilk olarak telesiyej yapımı, kayak evi, konaklama tesisi, helikopter pistiyle birlikte idari ve sosyal tesisler inşa edilmiştir. Sosyal tesisler, restoran, idare ve hizmet binası 2017 yılında faaliyete geçmiştir (http://www.ordukulturturizm.gov.tr).

650 dönüm üzerine kurulan ve 2 bin rakıma sahip Çambaşı Kış Sporları ve Kayak Merkezi 2017 y1lı itibariyle hizmete girmiş bulunmaktadır. Mülkiyeti Maliye Hazinesine, kullanım hakkı Ordu Büyükşehir Belediyesi’ne ait tesis alınan büyükşehir meclisi kararıyla on seneliğine işletmeciliği ORBEL A.Ş’ ye verilmiştir. Kayak merkezinde 1.753 metre ve 1.104 metre uzunluğuna sahip 2 adet telesiyej hattı mevcuttur. Toplam uzunluğu 17.275 metreye sahip 11 adet kayak pisti yer almaktadır. Ayrıca, tesis içinde 40 kişi kapasiteli 12 odaya sahip otel, Slalom Kafe, Vargel Kafe, Kozalak Kafe ve Zirve Kafe adında sosyal anlamda restoranlar ile kayak malzemeleri kiralama ve satış noktaları bulunmaktadır (http://cambasidoga.com). Çambaşı Kış Sporları ve Kayak Merkezi ülkemizin önde gelen kayak merkezleri kadar popülerliğe sahip olmasa da yerel anlamda faaliyet gösteren bir kayak merkezidir.

\subsection{Araştırmanın Amacı ve Önemi}

Günümüzde turizm sektörü ülkeler açısından büyük önem arz etmektedir. Özellikle az gelişmiş ve gelişmekte olan ülkeler sahip oldukları turizm arzından olabildiğince yararlanmaya çalışmaktadır. Kış turizmi gibi turizm sektörünün bütün yıla dengeli şekilde yayılmasına olanak sağlayan alternatif turizm türlerinin ülkelerin turizm stratejileri açısından oldukça önemli olduğu söylenebilir. Bu bağlamda, bu araştırmanın temel amacı özellikle son dönemde gelişen ve üzerine bilimsel çalışmalar yapılan alternatif turizm türlerinden biri olan kış turizminin yerel kalkınmaya yaptığı etkileri incelemek ve önemini belirtmektir. Araştırmanın temel amacına yönelik olarak Türkiye'de yerel düzeyde önemli bir yere sahip, kış turizmi açısından bir değer olan ve gerek doğal güzellikleriyle gerekse kültürüyle insanları cezbeden Ordu ili araştırma bölgesi olarak belirlenmiştir. Ayrıca, araştırma kapsamında Ordu ilinin seçilmesinde, zengin bir turizm potansiyeline sahip olmasına rağmen yöreyle alakalı olarak çok az bilimsel araştırma bulunması ve kış turizminin bölgede çok yeni olması etkili olmuştur.

\subsection{Araştırmanın Yöntemi}

Araştırmada nitel araştırma yönteminin fenomenoloji yaklaşımı çerçevesinde araştırma süreci şekillendirilmiştir. Araştırmada veri toplama tekniği olarak, katılımcılarla yüz yüze görüşme/mülakat tekniği kullanılmıştır. Araştırmada veri toplama aracı olarak yarı yapılandırılmış mülakat formu kullanılmıştır. Mülakat tekniğinin kullanılmasındaki amaç ise, ulaşılmak istenen verilerin belli kategorize edilmiş ölçekli sorularla ulaşamamanın 
güçlüğünden kaynaklanmaktadır. Yarı yapılandırılmış mülakat tekniği sayesinde araştırmacı, tam yapılandırmış mülakata oranla görüşmenin seyrine göre sorularda birtakım değişiklikler yapıp, aynı zamanda ek sorular yöneltebilmektedir (Merriam, 2013). Yarı yapılandırılmış mülakat ile yürütülen araştırmaya dâhil edilen katılımcılar ile telefon görüşmeleri sonucu randevu alınmış ve kabul edilen randevular sonucunda yerel yönetimler, sivil toplum kuruluşları, Ordu Üniversitesinde görev yapan turizm alanındaki akademisyenler ve turizm işletmelerinden ulaşılabilen üst ve orta kademe yöneticiler çalışmaya katılımcı olarak dâhil edilmiştir. Görüşme sırasında ses kayıt cihazı bulundurulmuş, katılımcıların izni dâhilinde kayıt yapılmış ve önemli noktalar da ayrıca not alınmıştır. Katılımcılarla gerçekleştirilen görüşme süresi ise yaklaşık 35-40 dakika civarındadır. Görüşmede kullanılan soru formunun oluşturulmasında, yapılan ulusal ve uluslararası literatür incelemesi dikkate alınmış ve daha önce benzeri konularda mülakat formu hazırlamış konuyla ilgili uzmanlığa sahip iki akademisyenin fikirlerinden yararlanılmıştır. Yapılan çalışmalar sonucunda araştırma konusunu en doğru şekilde yansitacak soruların hazırlanması amaçlanmış ve mülakat sorularının hangi amaçlarla katılımcıya yöneltilecekleri netleştirilerek mülakat formu oluşturulmuştur.

\subsection{Araştırma Evreni ve Örneklemi}

Türkiye' de kış turizmi açısından öneme sahip olan Uludağ, Palandöken, Kartalkaya ve Köroğlu gibi önemli destinasyonlar bulunmaktadır. $\mathrm{Bu}$ araştırmanın evreni de ele aldığı konular bakımından bu destinasyonlarla ilişkilidir. Bu bağlamda, Ordu il merkezi ve Kabadüz İlçesi’nde yer alan yerel yönetim otoriteleri, turizm işletmeleri, esnaf ve zanaatkârlar, Sivil Toplum Kuruluşlarındaki üyeler, Ordu Üniversitesi Sosyal Bilimler Meslek Yüksekokulu Turizm İşletmeciliği Bölümü'nde görev yapan akademisyenler ile Kabadüz ilçesinde yer alan Çambaşı Kış sporları ve Kayak Merkezi temsilcileri araştırmanın çalışma evrenini oluşturmaktadır. Bu evren içerisinde zengin bilgiye sahip olduğu düşünülen durumların derinlemesine çalışılmasına olanak vermek amacıyla amaçlı örneklem seçilmiştir. Ordu ilindeki kış turizmi aktiviteleri ile ilişkili oldukları ve bu aktivitelerle ilgili gözlemlerinin bulunduğu varsayımına dayalı olarak ilgili katılımcı grupları tercih edilmiştir. Bu kapsamda toplam 24 katılımcıdan veri elde edilmiştir.

\subsection{Araştırma Bulguları}

Araştırmada verilerin toplanması aşamasında katılımcıların izniyle ses kayıt cihazı kullanılmıştır. Daha sonra ses kaydı şeklinde gerçekleştirilen mülakatlar, araştırmacı tarafından yazılı bir metne dökülmüştür. İkinci bölümde elde edilen metinler araştırmacı ve bir uzman 
tarafından ayrı ayrı değerlendirilerek temel analiz konuları (temalar) saptanmıştır. Bu aşamada gerçekleştirilen mülakat tekniğinin geçerliliğinin kontrolü maksadıyla, araştırmacı ve uzman tarafından saptanan temaların benzerlik derecesi de karşılaştııılmıştır. Bu bağlamda, araştırmacılar tarafından araştırmanın amacına hizmet edeceği düşünülen 15 tema üzerinde odaklanılmasına karar verilmiştir. Her bir temayla ilgili bilgi toplamak amacıyla katılımcılara toplam 15 soru sorulmuştur. Temaların yorumlanmasında araştırmacı mülakat formlarında yer alan sorularla ilgili betimsel bir analiz yaparak temalarla ilgili genel görüşleri ifade eden çıkarımlarda bulunmuştur. Ayrıca, araştırmada konunun daha iyi anlaşılabilmesi için temalarla ilgili önemli görülen yanıtlar italik olarak ve tırnak içinde (“") vermiştir.

\subsubsection{Katılımcıların Demografik Özellikleri}

Aşağıda Tablo 1'de görüldüğü üzere araştırma kapsamında mülakat gerçekleştirilen katılımcıların çoğunluğu erkeklerden (n: 15) oluşmaktadır. Katılımcıların eğitim düzeyleri incelendiğinde 13 katılımcı lisans mezunu iken, 6 katılımcı lisansüstü, 3 katılımcı ön lisans, 2 katılımcının da ortaöğretim muzunu olduğu göze çarpmaktadır. Bu bağlamda, mülakat gerçekleştirilen katılımcıların konuyla ilgili yeterli bilgi birikimine sahip olduğunu söylemek mümkündür.

Tablo 1. Katılımcıların Demografik Özellikleri

\begin{tabular}{|c|c|c|c|c|c|c|c|}
\hline \multicolumn{2}{|c|}{ CINSIYYET } & \multicolumn{2}{|l|}{ MESLEK } & \multicolumn{2}{|c|}{ EĞíTiM DURUMU } & \multicolumn{2}{|c|}{$\begin{array}{l}\text { ORDU } \quad \text { ÍLÍNDEKİ } \\
\text { İKAMET SÜRESİ }\end{array}$} \\
\hline Kadın & 9 & Kamu Sektörü & 14 & Ortaöğretim & 2 & $0-5$ Yil & 6 \\
\hline Erkek & 15 & Özel Sektör & 10 & Ön Lisans & 3 & $5-10 Y_{11}$ & 1 \\
\hline \multicolumn{4}{|c|}{ TURİZM SEKTÖRÜ İLE BAĞI } & Lisans & 13 & $10-15$ Yil & 2 \\
\hline \multicolumn{3}{|c|}{ Turizm Sektöründe Aktif Çalışan } & 18 & Lisansüstü & 6 & 15-20 Y1l & 2 \\
\hline \multicolumn{3}{|c|}{ Turizm Sektöründe Çalışmıyor } & 6 & & & 20 ve Üstü & 13 \\
\hline
\end{tabular}

$(\mathrm{N}=24)$ 


\subsubsection{Temaların Yorumlanması}

Araştırma amacına yönelik olarak geliştirilen yarı yapılandırılmış mülakat formu aracılığı ile toplanan veriler araştırmacılar tarafından Tablo 2'deki temalar dikkate alınarak betimlenmiştir.

Tablo 2. Araştırma Temaları

\begin{tabular}{|l|l|}
\hline Tema 1 & Kış turizmi potansiyeliyle ilgili analiz \\
\hline Tema 2 & Ziyaretçi sayısını ve gelen turistlerin profilini belirlemeye yönelik analiz \\
\hline Tema 3 & Gelen turist sayısını arttırmaya yönelik analiz \\
\hline Tema 4 & Kış turizmi açısından olumsuzluk yaratan unsurlara yönelik analiz \\
\hline Tema 5 & $\begin{array}{l}\text { Kış turizminin yöredeki diğer turistik değerlerin korunması üzerindeki } \\
\text { etkisine yönelik analiz }\end{array}$ \\
\hline Tema 6 & Kış turizminin yöredeki altyapı hizmetlerini etkilemesine yönelik analiz \\
\hline Tema 7 & Kış turizminin yöre halkının gelir durumuna katkısının analizi \\
\hline Tema 8 & Kış turizminin yöredeki diğer sektörlere katkısının analizi \\
\hline Tema 9 & Kış turizminin yöresel ürün ve hizmetlerde talep artışına yönelik analiz \\
\hline Tema 10 & Kış turizminin yöredeki istihdam üzerine etkisinin analizi \\
\hline Tema 11 & Kış turizminin yöredeki göçü engellemesine yönelik analiz, \\
\hline Tema 12 & Kış turizminin yöredeki yatırımlara etkisinin analizi, \\
\hline Tema 13 & \begin{tabular}{l} 
Kış turizminin gelişiminde kamu kurumları/özel işletmelerin rolünün analizi \\
\hline Tema 14
\end{tabular} \begin{tabular}{l} 
Yerel halkın kış turizmine yönelik tutumu ile ilgili analiz \\
\hline Tema 15
\end{tabular} $\begin{array}{l}\text { Kış turizminin yöredeki sosyo-kültürel yapı üzerindeki etkisine yönelik } \\
\text { analiz }\end{array}$ \\
\hline
\end{tabular}

\section{- Ordu İlinin Kış Turizmi Potansiyeliyle İlgili Analiz}

$\mathrm{Bu}$ kapsamda ilk olarak yöneltilen “Ordu'nun kış turizmi potansiyeliyle ilgili düşünceleriniz nelerdir?” sorusuna katılımcıların çok büyük bir çoğunluğu (n: 23) “Ordu ilinde kış turizm potansiyelinin yüksek olduğu” şeklinde görüş bildirmişlerdir. Katılımcılardan sadece 1 kişi potansiyelin çok düşük olduğu ve Ordu ilinin diğer turizm çeşitleri ile daha çok özdeşleştiği yönünde görüş bildirmiştir. Kış turizmi potansiyeli açısından Ordu ilinin 2010 yılından itibaren Çambaşı kayak merkezinin geliştirilmesi ile birlikte kış turizminin başladığı yüksek potansiyelinin olduğu ancak bu potansiyelin tanıtım ile güçlendirilmesi gerektiğini savunmuşlardır. 
Katılımc1 17 “Ordu’nun kış turizmi özellikle bu sene çok gelişti. Sömestr döneminde yaklaşık 80 bin kişiyi ilçemizde ağırladık. Bu durum ilçemizdeki kış turizmi potansiyelinin ilerleyeceğini gösteriyor."

\section{- Ordu İline Kış Turizmi Açısından Ziyaretçi Sayısını ve Gelen Turistlerin Profilini}

\section{Belirlemeye Yönelik Analiz}

Ordu iline kış turizmi açısından gelen turistlerin profilini belirlemeye yönelik olarak sorulan soruda katılımcılarla öncelikle "2019 yılı itibariyle Ordu’yu 967.741 kişinin ziyaret ettiği” bilgisi paylaşılmıştır. Bu sayısının ne kadarının kış turizmi kapsamında Ordu’yu ziyaret ettiği, yerli ve yabancı turist sayısının dağılımı hakkındaki görüşleri alınmıştır. Katılımcıların büyük bir çoğunluğu (n:23), “Yöreyi kış turizmi açısından ziyaret eden turist sayısı yetersiz” şeklinde cevap verirken 1 katılımcı ise sayının yeterli olup olmadığına dair görüş bildirmemiş ve tahmini rakam vermiştir. Örneğin; Katılımcı 2 "Çambaşı kayak tesisimiz daha yeni açıldı. Bu anlamda da yeni yeni dikkat çekmeye başladı. Tesis çok yeni olduğu için sayı olarak yetersiz. Bu bir süreç ve hedeflere büyük ölçüde 2023 'te ulaşılacaktır. Tüm koşullar tamamlandığında klş turizmi açısından Çambaşı Kayak Merkezi patlama yapabilir.” Buradan hareketle geçen seneye göre kış turizmi açısından yöreyi ziyaret eden kişi sayısının artmasına rağmen henüz yetersiz olduğu söylenebilir. Fakat umut verici bir başlangıç olduğunu ve ileriye dönük daha çok insanın Çambaşı Kayak Merkezini ziyaret edeceğini söylemek mümkündür. Yöreyi ziyaret eden turistlerin profilini belirlemeye yönelik sorulan soru sonucunda ise kat1lımcıların tamamı (n:24), "Yöreyi kış turizmi açısından ă̆ırlıklı olarak yerli turist ziyaret ediyor ve çevre illerden ziyaret daha fazla” olarak görüşlerini belirtmişlerdir. Katılımcı 1'de “...Profesyonel kayakçılar daha gelmeye başlamadı ama, bireysel olarak kayak yapmaya gelenler, çevre illerden gelenler var. Yabancidan ziyade yerli turist dediğimiz Trabzon'dan, Rize'den, Giresun'dan, Sivas ve Samsun taraflarından gelip burada kayak yapan, eğitim alan insanlar var." yönünde görüş belirterek yukarıdaki çıkan sonucu bir nevi doğrulamaktadır.

Ordu iline kış turizmi açısından gelen ziyaretçi sayısı ve gelen turistlerin profilini belirlemeye yönelik analiz sonucunda kış turizmi açısından ziyaret eden turist sayısının henüz yeterli düzeylere ulaşmadığı söylenebilir. Yöreyi kış turizmi açısından ağırlıklı olarak yerli turist ziyaret ederken bunların büyük bir kısmı çevre ilerden gelmektedir. Yabancı turist sayısı ise çok az olmakla birlikte yöreyi Körfez ülkelerinden gelen turistler daha fazla ziyaret etmektedir.

\section{- Ordu İline Kış Turizmi Açısından Gelen Turist Sayısını Arttırmaya Yönelik Analiz}

Araştırmaya yönelik sorulan "Kış turizmi açısından yöreyi ziyaret eden turist sayısını arttırmak için sizce neler yapılabilir?” sorusuna katılımcıların büyük bir çoğunluğu (n:20) 
“Tanıtım ve pazarlama faaliyetlerinin yapılması gerekli” şeklinde görüşlerine yer vermişlerdir. Buna örnek olarak Katılımcı 3 “En büyük tanıtım ve pazarlamaya önem verilmeli. Yeni tanıtım sistemlerini devreye sokmall. Özellikle tanıtım mecralarında, fuarlarda, büyük organizasyonlarda bu türlü görüşmelerde potansiyeli anlatmak lazım. Ürünümüz çok güzel olabilir, kaliteli olabilir. Ĕger tanıtamazsanız, pazarlayamazsanız ve markalaştıramazsanız hiçbir anlamı yok. " diyerek reklam ve tanıtım faaliyetlerinin önemine dikkat çekmiştir. Bu bağlamda, katılımcıların çoğunluğu tanıtım açısından önemli olan sosyal medyaya dikkat çekmiştir. Tanıtım ve pazarlama faaliyetlerinin arttırılmasından sonra ise katılımcılar en çok (n: 12) alt-yapı çalışmalarına önem verilmesi gerektiğini savunmuştur. Diğer yandan dokuz katılımcı konaklama kapasitesinin arttırılması yönünde görüş bildirmiştir. Ulaşım imkânlarının geliştirilmesi (n: 4), yeni yatırımların geliştirilmesi gerektiği (n: 4), aktivitelerin çeşitlendirilmesi (n: 4) katılımcıların sundukları diğer önerilerdir.

\section{- Ordu İlinde Kış Turizmi Açısından Olumsuzluk Yaratan Unsurlara Yönelik Analiz}

Tema ile ilgili olarak katılımcılara yöneltilen "Ordu’ya yönelik kış turizmi kapsamında yerli ve yabancı turist ziyaretini olumsuz etkileyen veya etkileyebilecek unsurlar sizce nelerdir?" sorusuna katılımcıların çoğunluğu (n: 20), "Ulaşılabilirlik açısından sıkıntı yaşanıyor ve yol problemi var” şeklinde görüşlerini belirtmişlerdir. Örnek olarak Katılımc1 17 "En önemli sorunumuz ulaşım diyebilirim. Aslında havaalanından çıktıktan sonra Kabadüz ilçemize kadar güzel double bölünmüş yollarımız var. Çambaşı yoluna girdikten sonra biraz sıkıntımız var. $O$ yol biraz insanı zorluyor. Yolun hem dar olması hem virajlı olması hem de tepeye çıkıp geri inmek gibi durumlardan dolayı biraz zorluyor.” şeklinde görüş bildirerek ulaşımın güçlüğüne ve yol sorununa vurgu yapmıştır.

$\mathrm{Bu}$ temaya yönelik sorulan soruya istinaden daha önceden şıklar belirlenmiş ve katılımcıların cevaplarına göre bu şıklar işaretlenmiştir. Araştırmadaki bulgular neticesinde 20 kişi ulaşımın güçlüğüne değinmiştir. 17 kişi konaklama işletmelerinin nitelik ve kapasite olarak yetersiz olması ile ilgili görüş bildirmiştir. Sosyo-kültürel aktivitelerin yetersizliği konusunda 16 kişi görüş bildirmiştir. Katılımcılardan 8 kişi ise yörenin henüz turistik açıdan markalaşmadığını savunmuştur. Altyapı hizmetlerinin yetersiz kaldığı görüşünde ise 7 katılımcı yer almaktadır. Yerel halkın olumsuz tutumlar sergilediğine yönelik 6 katılımcı, iklimsel özelliklerin uygun olmaması yönünde 3 katılımcı ve yörenin turistik açıdan pazarlanamamasıyla ilgili olarak 2 katılımcı görüş belirtmiştir. Yerel halkın olumsuz tutumlar sergilediğini belirten katılımcılar buna örnek olarak bazı taksicilerin turistlerden yüksek ücret almasını ve esnafın turistlerle iletişim tarzlarındaki sıkıntıları göstermiş̧ir. Ayrıca, bu sorunun 
şıkları arasında yer alan güvenlik endişesi hakkında hiç kimse görüş belirtmemiştir. $\mathrm{Bu}$ bağlamda katılımcıların tamamının yöreyi güvenli bulduğunu söylemek mümkündür.

\section{- Ordu İli Kış Turizminin Yöredeki Diğer Turistik Değerlerin Korunması Üzerindeki} Etkisine Yönelik Analiz

Araştırmada "Yöredeki turistik değerlere gereken önem veriliyor mu? Kış turizminin yöredeki gelişimi turistik değerlerin korunması ile ilgili bilinci sizce nasıl etkilemiştir?” sorusuna katılımcıların çoğunluğu (n: 16), yöredeki turistik değerlere gereken önemin verildiğini ve koruma bilincinin son zamanlarda oluşmaya başladığını belirtmiştir. Katılımcıların geri kalanı ise yöredeki turistik değerlere gereken önemin verilmediğini, henüz bu bilincin oluşmadığını ve zaman içerisinde doğal çevrenin tahribata uğradığını savunmaktadir.

\section{- Ordu İli Kış Turizminin Yöredeki Altyapı Hizmetlerine Etkisi ile İlgili Analiz}

Araştırmada yöneltilen "Yöredeki kış turizminin gelişimine paralel olarak yöredeki altyapı hizmetlerinin de gelişim gösterdiğini düşünüyor musunuz?” sorusuna katılımcıların çoğunluğu İlçede kayak merkezinin açılması ve o destinasyonun kış turizmine kazandırılması ile birlikte alt yapı çalışmalarının hızlandırıldığına yönelik görüş bildirmişlerdir. Ayrıca, yöneltilen soruya olumsuz şekilde görüş bildiren katılımcılar ise alt yapının yetersiz olduğu bölgenin kış turizme kazandırıldı̆̆ı ancak bölgenin karayolu açısından yetersiz kaldığını savunmuştur. Buna örnek olarak Katılımc 6 “Ordu deyince aklımıza gelen iki önemli faktör var. Bunlardan birisi Çambaşı birisi ise Boztepe. Ama bu iki noktaya giden yollara baktığımızda halen köy yolu gibi olduğunu söylememiz yanlış olmaz. Halen iki aracın yan yana geçmekte zorlandı̆̆ yollar. Biz kendi insanımız oralara gitmek için gözümüzde büyürken bir sıkıntı yaşayacak mıyız diye çekincemiz varken dışarıdaki insanı nasıl getirelim. Eksiklik var." şeklinde alt yap1 hizmetlerinin çok yetersiz kaldığını savunmaktadır. Dolayısıyla alt yapının ve turizmin gelişmesinin birbirine paralel olduğu, alt yapının gelişmesiyle destinasyonun ulaşılabilir olacağı veya turizmin gelişmesiyle o bölgeye alt yapı hizmetlerinin hızlandığı yadsınamaz bir gerçektir. Katılımcıların görüşlerine istinaden alt yapı çalışmaları hakkında yerel yönetimlerin çalıştığı ancak çalışmaların bölgedeki talebe karşı yetersiz kaldığı görülmektedir.

\section{- Ordu İli Kış Turizminin Yöre Halkının Gelir Durumuna Katkısının Analizi}

Araştırmada yedinci soru olarak, "Kış turizminden elde edilen gelirin yöre halkının gelirine katkı sağlayacă̆ını düşünüyor musunuz?” sorusu sorulmuştur. Katılımcıların çoğunluğu (n: 20), kış turizminden elde edilen gelirin yöre halkının gelirine olumlu bir katkı sağladığ1 yönünde görüş bildirirken, 3 katılımcı kış turizminden elde edilen gelirin şu an için yöre halkının gelirine henüz çok fazla bir katkısının olmadığını düşünmektedir. Ayrıca, 1 katılımcı 
kayak merkezinin 2 yıldır faaliyette olduğunu ve bu nedenle yöre halkına bir gelir sağlayıp sağlamadığını şu anda görmenin çok zor olduğunu belirtmiştir.

Katılımcılar arasında esnaf olan Katılımcı 5 “...Yöre halkına olumlu bir etkisi var. Ben burada bir esnaf olarak yöreye özgü işlenmiş findık ürünü ve mamullerini satıyorum. Yöreyi ziyarette bulunan herkes bu ürünlere karşı ilgi duyuyor ve şehirden ayrllırken satın alıyorlar. Dolayısıyla bu da benim gelirime olumlu yönde katkı sağllyor...” demiştir.

$\mathrm{Bu}$ temayla ilişkili olarak "Kış turizmi yerel kalkınmayı nasıl etkiler? diye ek bir soru sorulmuştur. Bu soruya Katılıme 17 “İnsanlarımız kış turizminden bir gelir elde ediyorlar. Tabi sadece kış turizminden değil yaz ayları da var. Karın yerde kalma süresi bittiğinde başka sektörlere yönelik geçimini să̆lamak zorundalar. Tabi buradan iyi gelir elde edince insanlarımız başka bir seçenek olarak tarım ve hayvancılığa yönelecekler. Fındık dikimi olacak ve insanlar hayvancılıkla uğraşacak. Buradan elde edilen gelirler keza başka sektörlere aktarılacak. Burada bir çarpan etkisinden söz etmek mümkündür. Ayrıca, bir katma değer olacaktır." şeklinde yanıt vermiştir.

Araştırma neticesinde bu temada genel olarak şu sonuçlar ortaya çıkmıştır. Kış turizminden elde edilen gelirler yöre halkının gelirine olumlu bir katkı yapmaktadır. Kış turizmi yerel kalkınmayı hızlandırıcı bir nitelik taşımakta ve şehre bir hareketlilik kazandırmıştır. Ayrıca, kış turizmi, tarım sektörüne karşı tamamlayıcı bir rol oynamaktadır.

\section{- Ordu İli Kış Turizminin Yöredeki Diğer Sektörlere Katkısının Analizi}

Araştırmanın sekizinci sorusu olan "Yöredeki kış turizmi faaliyetlerinin diğer sektörlere de ekonomik anlamda katkı yaptığını ya da yapacağını düşünüyor musunuz? (Tarım, Sanayi, Hizmet vs.). Kış turizmindeki gelişmeler sizce hangi sektörleri olumlu etkileyebilir? ” sorusuna katılımcıların tamamı Kış turizminin gelişmesiyle hizmet sektörlerini pozitif olarak etkilediğini söylemiştir. Ayrıca, katılımcıların büyük bir çoğunluğu (n: 20) "Kış turizminin gelişmesi tarım sektörünün gelişimine de katkı sağlayacaktır” yönünde düşünürken, katılımcıların bir kısmı (n: 4) “Kış turizminin tarım sektörünü az etkilediğini” ş̧eklinde görüşlerini ifade etmişlerdir. Katılımcıların bir kısmı (n: 7), “Kış turizminin sanayi sektörüne olumlu katkı yaptı̆̆g” yönünde görüş belirtirken, sekiz katılımcı "Klş turizminin sanayi sektörünü dolaylı yollardan ve az etkilediğini" söylemiş ve katılımcıların geri kalan kısmı (n: 9), ise "Kış turizminin sanayi sektörüne bir etkisinin olmadĭ̆ "ş̧eklinde yanıt vermiştir.

\section{- Ordu İli Kış Turizminin Yöredeki Ürün ve Hizmetlerde Talep Artışı İle İlgili Analiz}

Araştırmada "Kış turizmi bağlamında, sizce yöredeki ürün ve hizmetlere karşı kayda değer bir talep artışı yaşanıyor mu? Hangi ürün ve hizmetlerin kış turizmi sebebiyle daha yoğun talep gördüğ̈̈nü gözlemliyorsunuz?” sorusuna katılımcıların büyük bir çoğunluğu (n: 20), yöredeki 
ürün ve hizmetlere karşı bir talep artışı olduğu şeklinde görüş bildirmiş ve dört katılımcı ise "Henüz yöredeki ürün ve hizmetlere karşı bir talep artışı yaşandığını düşünmüyorum” diye cevap vermiştir.

Yöredeki ürün ve hizmetlere karşı bir artış olduğunu belirten Katılımcı 5 "Bence talep artışı yaşanıyor. Illk başta findık olmak üzere onun dışında lokum, pestil, köme vb. ürünleri çok tüketiyorlar. Tatll gruplarını çok seviyorlar. Yine Perşembe'nin cevizli helvası var. Hediyelik eşya açısından magnetlere ilgi var. Peştamal ve yine çini işlemeli kahve takımlarını seviyorlar." diye görüş belirtmiştir.

$\mathrm{Bu}$ bağlamda, kış turizminin gelişmesiyle yöresel ürün ve hizmetlerde bir talep artış1 yaşandığını söylemek mümkündür. Ayrıca, bu artış daha çok yiyecek ürünleri olan yöreye özgü fındık ve mamulleri, bal, kivi, Perşembe'nin cevizli helvası, Akkuş fasulyesi, kuzu eti, Kibele çikolatası satışında yaşanmaktadır. Bunun yanı sıra, yöreye özgü otantik değerleri yansıtan hediyelik eşyalar ve el sanatları ürünlerinde de bir artış olduğu gözlemlenmektedir.

\section{- Ordu İli Kış Turizminin Yöredeki İstihdam Üzerine Etkisinin Analizi}

Araştırmanın onuncu sorusu olan "Klş turizminin yerel halka istihdam sağlamada önemli bir role sahip olduğunu düşünüyor musunuz?” sorusuna katılımcıların büyük bir çoğunluğu (n: 19) kış turizminin yöre halkına istihdam sağlamada önemli bir role sahip olduğunu belirtirken, katılımcıların geriye kalan kısmı (n: 5) kış turizmi açısından istihdamın şu an için yetersiz olduğunu belirtmiştir. Katılımcı 10 "Muhakkak turizmin her çeşidi yerel halka istihdam sağlayacaktır. Hangi çeşit olursa olsun. Kış turizmi de aynı şekilde. Kış turizmi için açılan tesislerin bir avantajı daha var yazın da kullanılabiliyor. Yazında oraya gelen insanlara bu hizmetleri sunabiliyorsunuz. Dolayıslyla 12 ay boyunca hizmet verdiği için yerel halka istihdam sağlamada önemli bir role sahip olacaktır. En çok yiyecek-içecek alanında istihdama ihtiyaç olacaktır. Daha sonrasında kayak tesisinde çalışan kayakla ilgilenen, bilen, anlayan bu konuda uzman personele ihtiyaç duyulacaktır. Üçüncü olarak konaklama sektörüne istihdam sağlayacaktır." şeklinde görüşünü bildirmiştir. Buradan hareketle, kış turizminin gelişmesiyle birlikte yerel halka istihdam sağlamada önemli bir rol oynayacağını söylemek mümkündür.

\section{- Ordu İli Kış Turizminin Yöredeki Göçü Engellemesine Yönelik Analiz}

Gerçekleştirilen mülakatta "Yöredeki kış turizminin gelişimi başka yörelere olan göçü engeller mi? "’ sorusuna katılımcıların büyük bir çoğunluğu (n: 23) kış turizminin gelişmesinin göçü engelleyeceğini düşündüğü yönünde cevap vermiştir. 1 katılımc1 ise göçü engellemeyeceğini belirtmiştir. Göçü engelleyeceğini düşünen Katılımcı 10 "Muhakkak engeller. Çünkü burada çalışacak olan insanlar başka bir yere gidip bu işlerle falan uğraşmayacaklardır. Kış turizminin gelişmesiyle yöredeki küçük işletmeler artık 
kapanmayacaktır. Yaylaya eğitim ve sağlık gibi hizmetler gittiği takdirde insanlar şehir merkezine inmeyecektir." şeklinde düşüncelerini yansıtmıştır.

\section{- Ordu İli Kış Turizminin Yöredeki Yatırımlara Etkisinin Analizi}

“Kış turizmi organizasyonları ekseninde, yöredeki yatırımlarda sizce bir artış mümkün müdür? ” sorusuna katılımcıların çok büyük bir çoğunluğu (n: 23), "Kış turizminin gelişmesiyle beraber yöredeki yatırımların artacağg”" yönünde cevap vermiştir. Bir katılımcı bu konu ile ilgili görüş belirtmemiştir. Katılımc1 7'nin görüşü 'Yatırımların artması tabi ki mümkündür. Organizasyon arttıkça yatırım olacaktır. Şu andaki mevcut konaklama yerleri yeterli değil. Yeni yeni yerler yapılacak. Sayı artacaktır. Öyle bir arazide, öyle bir doğada yapılabilecek bir sürü şey var. Insanlar yeni fikirlerle gelecektir. Doğa çok güzel ve yatırımların önü çok açık." şeklindedir.

\section{- Kış Turizminin Gelişiminde Kamu Kurumları/Özel İşletmelerin Rolünün Analizi}

Araştırmada kamu kurumları ile özel işletmelerle ilişkili olan "Sizce kış turizmi faaliyetlerinin gelişimine yönelik Kamu kurumları/Özel işletmelerin çabaları yeterli midir?” sorusuna katılımcıların çoğunluğu (n: 17), "Kamu kurumları/Özel işletmelerin çabalarının yeterli olduğu” yönünde görüş birliğine varırken, 6 katılımc1 "Çabaların olduğu fakat bu çabaların yetersiz olduğunu” belirtmiş, 1 katılımcı ise "Çabalar adına olumlu bir şey görmüyorum" şeklinde görüş bildirmiştir.

Kamu kurumları ve özel işletmelerin çabalarının yeterli olduğuna örnek olarak, Katılımcı 18 “Kamu kurumlarının çabalarını yeterli görüyorum. Özellikle Ordu Büyükşehir Belediyesi ve Kabadüz Belediyesi gece gündüz çalışlyorlar. Altyapı yapmaya çalışıyorlar. Ellerindeki kaynaklarl en iyi şekilde kullanmaya çalışlyorlar. Il Kültür ve Turizm Müdürlüğü'nün çalışmaları da burada başarılı. Özel işletmeler olarak bizde elimizden geldiği kadar çabaliyoruz. Ordu turizmine, Türk turizmine ve Dünya turizmine bir şeyler katmaya çalışıyoruz." şeklinde düşüncelerini ifade etmiştir.

Temanın değerlendirilmesi noktasında yorumlarda bulunan esnaf, özel işletme çalışanları ve kış turizmi merkezi temsilcileri çabaların yetersiz olduğu yönünde cevap verirken, kamu kurumlarında görevli olan kişilerin çabaları yeterli olarak bulması göze çarpmaktadır.

\section{- Ordu İlindeki Yerel Halkın Kış Turizmine Yönelik Tutumu İle İlgili Analiz}

Araştırmada on dördüncü sırada yer alan "Sizce yerel halk turizm faaliyetleri (Kış Turizmi) açısından yöreyi ziyaret eden turistlere karşı yeterli derecede bilinç sahibi mi?" sorusuna, katılımcıların çoğunluğu (n: 16), kış turizminin yörede daha çok yeni olması sebebiyle bu bilincin yerel halkta yeni oluşmaya başladığ 1 cevabı vermiştir. Katılımcıların bir kısmı (n: 6), ise bu bilincin henüz yeterince oluşmadığını ve zaman içerisinde oluşacağını belirtmiştir. 
Bölgede turizm faaliyetlerinin bölgede yeni olması sebebiyle yerel halkın turizmin olumlu etkilerini gözlemlemediği ve bununla ilişkili olarak turizm faaliyetleri ile ilgili henüz yeterli bilinç düzeyinin oluşmadığı söylenebilir. İki katılımcı ise bu konuda görüş belirtmemiştir.

\section{- Ordu İli Kış Turizminin Yöredeki Sosyo-Kültürel Yapı Üzerindeki Etkisine Yönelik}

\section{Analiz}

Araştırmanın son sorusu olan "Kış turizminin geliştiği yörelerdeki sosyo-kültürel yapıda değişiklik yaşanıyor mu?" sorusuna katılımcıların yine büyük bir çoğunluğu (n: 19), kış turizminin gelişmesiyle birlikte sosyo-kültürel yapının değişime uğrayacağı yönünde ortak bir görüşe varırken, 4 katılımc1 "Henüz yöreye çok fazla bir talep olmadığ için sosyo-kültürel yapının değişiklik göstermesi zaman alacaktır” şeklinde görüş belirtmiş ve 1 katılımcı da "Klş turizminin gelişstiği yörelerde sosyo-kültürel yapıda değişiklik yaşanmaz” ş̧eklinde cevap vermiştir. Sosyo-kültürel yapının değişeceğini en güzel özetleyen Katılımcı 21 “Ciddi anlamda yaşanıyor. Tabi ki insanların tercihi bir kayak kültürü bölgede hiç yokken bir kayak kültürü başladı. Insanların aklına önceden turizm deyince sadece deniz-kum-güneş gelirken artık dağda kışın daha farklı, daha güzel bir tatil imkânının olduğunu görmeye başladı. Bu durum tabi ki insanların sosyal yaşantısında, tatil planlamasında farklllıklara gitmesini sevk etti. Bunlar söylemlere de, yaşantılara da, her şeye ciddi anlamda bir katkı sundu." şeklinde görüşünü belirtmiştir.

\section{Sonuç ve Değerlendirme}

Bölgesel kalkınmanın sağlanmasında yerelden başlayan bir kalkınma sürecinin planlanması oldukça önemlidir. Ordu ilinin yerel kalkınmasında turizm faaliyetleri son zamanlarda daha fazla önem kazanmaya başlamıştır. Ordu ilindeki turizm sektörü gelişiminde kış turizminin önemli bir rol üstleneceği düşüncesi bu araştırmanın hareket noktasını oluşturmaktadır. Ordu ilindeki kış turizminin yerel kalkınmaya yapmış olduğu etkiler bu çalışmanın kapsamında ele alınmıştır. Kış turizmi merkezi temsilcileri, yerel yönetim otoriteleri, turizm işletmeleri personeli, Ordu Üniversitesi Sosyal Bilimler Meslek Yüksekokulu Turizm İşletmeciliği Bölümü akademik personeli, sivil toplum kuruluşları ve esnaflardan oluşan 24 kişilik bir çalışma grubu ile yüz yüze mülakat gerçekleştirilmiştir. Bu mülakatlardan elde edilen veriler kullanılarak kış turizminin Ordu ilinde yarattığı etkiler ve ilin kış turizmi potansiyeli net şekilde ortaya koyulmaya çalışılmıştır.

Araştırmanın en önemli sonucu Ordu ilinde turizm ve kış turizmi faaliyetlerinin son 5-6 yıl içerisinde giderek ivme kazanmasına rağmen, turist sayısının (özellikle yabancı turist) henüz istenen seviyede olmamasıdır. Katılımcılar kış turizmi açısından yöreyi ziyaret eden turist 
sayısını arttırmak için reklam, tanıtım ve pazarlama faaliyetlerinin etkili olacağını düşünmektedir. Katılımcıların önemli bir bölümü Ordu ilinin kış turizmi için yeterli potansiyele sahip olduğunu düşünmekle birlikte, etkili pazarlama çalışmaları yapılmadığı için bu potansiyelin henüz yeterince kullanılamadığını düşünmektedir. Ordu ili tanıtımında Çambaşı Kayak Merkezi'nin tanıtımına yer verilmesi ve kayak merkezinin bilinirliğini arttırmak için ulusal ve uluslararası etkinliklere ev sahipliği yapılması pazarlama çalışmalarının etkisinin arttırılmasına katkı sağlayacaktır. Kış turizmi açısından yöreyi ziyaret eden turistlere karşı olumsuzluk yaratan durumların başında ise ulaşılabilirlik ve yol problemi olduğu belirlenmiştir. Konaklama ve rekreasyon işletmelerinin nitelik ve kapasite olarak yetersiz olması, sosyokültürel aktivitelerin yetersizliği, yörenin turistik açıdan markalaşmamış olması, altyapı yetersizliği, yerel halkın olumsuz tutumları, iklimsel özelliklerin uygun olmaması, hizmet kalitesi ve kalifiye personel eksikliği katılımcıların dile getirdiği diğer olumsuzluklardır.

Katılımcıların görüşleri bölgede kış turizminin gelişmesi için genel olarak pazarlama çalışmalarına önem verilmesi ve bölgedeki alt yapının iyileştirilmesi gereklilikleri üzerinde yoğunlaşmıştır ve eksikliklerin tamamlanması halinde ziyaretçi sayısında artış yaşanacağı düşünülmektedir. Ulaşım imkânlarının iyileştirilmesi, konaklama kapasitesinin arttırılması, aktivitelerin çeşitlendirilmesi katılımcıların ziyaretçi sayısını arttırmak için önerdikleri diğer çözümlerdir. Araştırma ulaşılan bir diğer önemli sonuç ise yöredeki kış turizmi gelişiminin mevcut tarihi ve turistik değerlerin korunması ile ilgili bilince katkı sağlamış olmasıdır. Katılımcılar, bölgede kış turizmi faaliyetlerinin gelişmesiyle yerel halkın bu değerleri koruma eğiliminin arttığını, yerel yönetimlerin ise bu değerlerin bakım ve restorasyon (yenileme) çalışmalarına daha fazla önem vermeye başladığını belirtmiştir.

Araştırmadan elde edilen veriler incelendiğinde, elde edilen bir başka sonuç ise yöredeki kış turizminin gelişmesinin diğer sektörlere yapacağı katkıdır. Gerçekleştirilen mülakatlarda katılımcıların tamamı kış turizminin hizmet sektörünü olumlu yönde etkileyeceğini belirtmiştir. Bunun yanı sıra katılımcıların bir kısmı yöredeki kış turizmi gelişiminin tarım sektörünü de olumlu anlamda etkileyeceğini belirtmiştir. Katılımcılar Ordu ilinde kış turizminin gelişmesi ve yatırımların artmasıyla birlikte yerel halk için önemli bir istihdam olanağının ortaya çıkacağını belirtmişlerdir. Ayrıca, katılımcılar işsizliğin azalmasıyla birlikte göçün azalacağı yönünde görüş bildirmişlerdir. Elde edilen veriler, katılımcıların kış turizminin yöresel ürünlere yönelik ek bir talep oluştuğu yönündeki ifadeye genel olarak $(n=20)$ katıldıklarını göstermektedir. $\mathrm{Bu}$ veriler katılımcıların, bölgenin kalkınmasında kış turizminin rolünün farkında olduğunu göstermektedir. 
Araştırmada yöredeki kış turizminin yeni olması sebebiyle yerel halkın yeni yeni bilinçlenmeye başladığı görülmüştür. Yörede daha önceden kış turizmi açısından herhangi bir faaliyet olmadığı için insanlar bu duruma yavaş yavaş alışmaktadır. Yöredeki kış turizminin gelişmesiyle katılımcıların büyük bir çoğunluğu sosyo-kültürel yapının değişime uğrayacağını düşünmektedir. Araştırma katılımcılarının, kış turizminin yatırımların artması ve göçün azalması konusunda bölgeye yapacağı katkının yeterince farkında olduğu görülmektedir. Bu olumlu katkıların yerel halkın tamamı tarafindan algılanmasıyla birlikte, katılımcıların bir olumsuzluk olarak belirttiği yerel halkın olumsuz tutumlarının da zamanla ortadan kalkacağı düşünülmektedir.

Yapılan araştırma sonucunda elde edilen bulgular, Çambaşı Kayak Merkezi'nin çok yeni bir tesis olması sebebiyle bölgesel kalkınma ve istihdam konusundaki etkilerin henüz yeterli seviyede olmadığını, fakat katılımcıların bu merkezin kış turizmi potansiyeline yönelik önemli beklentilere sahip olduklarını göstermektedir. Bu noktada, Çambaşı Kayak Merkezi ile ilgili paydaşların aktif olarak içinde bulunacakları planlama ve strateji geliştirme çalışmalarının yapılmasının oldukça önemli olduğu düşünülmektedir. Turizmin gelişme göstermesinin yerel kaynaklara bağımlı olduğu (Urry, 1987) bilinmektedir.

Araştırmada elde edilen bulgular genel olarak değerlendirildiğinde, Ordu ilinin kış turizmi açısından önemli çekiciliklere sahip olmakla birlikte, henüz bir kış turizmi destinasyonu olarak özellikle uluslararası anlamda yeterince bilinirliğe sahip olmadığı görülmektedir. Bölgede kış turizmi aktivitelerinin gerçek anlamda kalkınmaya katkı sağlaması, bölgeyi daha çok ziyaretçinin tercih etmesiyle mümkün olacaktır. Kış turizmine yönelik bölgeye olan talebin artması ise ancak etkili ve verimli pazarlama çalışmalarıyla mümkün olacaktır. Bu bağlamda Ordu ilinin kış turizminden daha fazla pay alabilmesi ve çekicilik yaratması için geliştirilen diğer öneriler aşağıda sıralanmıştır;

- Bölgenin ve kayak merkezinin tanıtım çalışmalarıyla ilgili bütünsel bir pazarlama stratejisi oluşturulmalıdır.

- Günümüzde insanların büyük çoğunluğu birçok konuyu sosyal medya üzerinden takip etmektedir. Bu anlamda da sosyal medya Çambaşı Kış Turizmi ve Kayak Merkezi'nin tanıtımı açısından etkin bir şekilde kullanılmalıdır.

- Kış turizmi açısından olumsuzluk yaratan durumların başında gelen ulaşılabilirlik ve yol problemi hızlıca çözüme kavuşturulmalıdır. 
- Kış sezonu boyunca yapılan kar festivalleri ve şenliklerin sayısı arttırılmalı, farklı etkinlikler oluşturulmalı ve bunlar aynı zamanda hem ulusal hem uluslararası nitelikte olmalıdir.

- Yörede kış turizminin yeni olması nedeniyle yerel halk turizm faaliyetleri açısından henüz yeterince bilinç sahibi değildir. Çeşitli eğitim seminerleri ve bilgilendirme toplantıları düzenlenerek yerel halkın turizm konusundaki bilinç düzeyi arttırılmalıdır.

- Ordu ili için turizm master planı oluşturulmalı ve toplumdaki tüm paydaşların bu konuda desteği alınmalıdır.

Kış turizminin yerel kalkınmaya yönelik etkilerinin incelendiği bu araştırmada ulaşılan sonuçlar önem teşkil etmekle birlikte kapsam ve yöntem açısından çeşitli sınırlılıklar içermektedir. Elde edilen sonuçlar Ordu ili ile sınırlıdır. Kış turizminin yerel kalkınmaya yapmış olduğu etkinin daha iyi anlaşılabilmesi için Ordu ilindeki kış turizmi faaliyetlerini konu alan çalışmaların artması gerekmektedir. Yapılacak olan araştırmalarda gerek nitel araştırma yöntemleri gerekse nicel araştırma yöntemleri kullanılarak daha geniş bir bakış açısıyla sonuçlar analiz edilmeli ve daha kapsamlı sonuçlara ulaşılması amaçlanmalıdır. Buna ek olarak, kış turizmi açısından Türkiye'de popüler olan Uludağ, Kartalkaya, Palandöken, Kartepe ve Ilgaz destinasyonları ile karşılaştırmalı olarak Çambaşı Kayak Merkezi değerlendirilerek merkezin gelecekteki potansiyelinin ortaya çıkmasında ne gibi eksikliklerin var olduğu daha net olarak ortaya koyulabilir. Ayrıca, Ordu ilinin yerel kalkınmasında turizm sektörünün ne kadar etkili olduğunun anlaşılması için kış turizminin diğer turizm türleriyle birlikte ele alındığı detaylı çalışmalar gerçekleştirilmeli ve ulaşılan sonuçlar uygulamaya konulmalıdır.

Son olarak, Ordu ilindeki turizm faaliyetleri üzerine gerçekleştirilen çalışmalar sınırlı sayıdadır. Bu bağlamda da yörede kış turizminin 2-3 senelik bir geçmişi olması nedeniyle bilimsel çalışmalar yok denecek kadar azdır. Bu araştırma, Ordu ilindeki kış turizmi açısından bir öncü niteliği taşımaktadır. Dolayısıyla, bu araştırma sonraki süreçlerde gerçekleştirilecek olan Ordu'daki kış turizmi ile ilgili çalışmalara bir dayanak noktası oluşturma potansiyeline sahiptir. Çambaşı Kayak Merkezi ile ilgili mevcut durumu ve potansiyeli ifade eden bu araştırmanın, gelecekte bölgenin potansiyelini güçlendirecek uygulamaya dönük katkılar yapacak araştırmalarla desteklenmesi oldukça önemlidir. Ordu ilinin kış turizmiyle ilgili gelişim sürecini şekillendirecek, farklı boyutlarıyla konuyu ele alan çalışmalara ihtiyaç bulunmaktadır. Özellikle Ordu ilinin kış turizmine yönelik destinasyon imajı, rekabet stratejileri gibi konuları ele alan çalışmalar uygulamada Ordu ilinin turizm sektöründeki gelişim sürecine katkı sağlayacaktır. 


\section{KAYNAKÇA}

Ağger, V. (2011). Üniversite 2011 Kış Oyunlarının Erzurum Kış Turizmi Potansiyeline Etkileri. Atatürk Üniversitesi. Sosyal Bilimler Enstitüsü, Coğrafya Ana Bilim Dalı, Yayımlanmamış Yüksek Lisans Tezi, Erzurum.

Akkuş, G. (2019). Ilgaz Dağında Kış Turizm Talebi ve Gelişimi. Çankırı Karatekin Üniversitesi İktisadi ve İdari Bilimler Fakültesi Dergisi, 9 (1), 1-27.

Atasoy, B. ve Kuter, F. Ö. (2005). Küreselleşme ve Spor. Uludă̆ Üniversitesi Eğitim Fakültesi Dergisi, 18(1), 11-22.

Berberoğlu, T. (2012). Etkinliklerin Destinasyona Etkileri: 2011 Erzurum Universiade Kış Oyunları, Dokuz Eylül Üniversitesi, Sosyal Bilimler Enstitüsü, Yayınlanmamış Yüksek Lisans Tezi, İzmir.

Bürki, R., Elsasser, H. ve Abegg, B. (2003). Climate Change And Winter Sports: Environmental And Economic Threats. 5th World Conference on Sport and Environment, Zurich, 1-9.

Cernaianu, S. ve Sobry, C. (2017). Romanya'da Kış Sporları Turizminin Gelişimi- Tarihsel Bir Yaklaşım. Avrupa Turizm Araştırmaları Dergisi, 16, 8-18.

Çakmak, F. ve Yılmaz, Ö. (2018). Turizmin İktisadi Sürdürülebilirliği Açısından Kış Turizmi, Hitit Üniversitesi Sosyal Bilimler Enstitüsü Dergisi, 11 (1), 267-286.

Demirhan, G. (1992). Dağcılıkta Spor-Turizm-Çevre İlişkisi. Anatolia Turizm Araştırmaları Dergisi, 3(5), $25-29$. Doğaner, S. (2001). Türkiye Turizm Coğrafyası. İstanbul: Çantay Kitabevi.

Evren, S. ve Kozak, N. (2018). Competitive Positioning Of Winter Tourism Destinations: A Comparative Analysis Of Demand And Supply Sides Perspectives-Cases From Turkey, Journal of Destination Marketing \& Management, 9, 247-257.

Gonseth, C. ve Vielle, M. (2018). İklim Değişikliğinin İsviçre Kış Turizmi Üzerine Uyumla Etkilerinin Genel Denge Değerlendirmesi, Environ Model Değerlendirmesi, 24, 265-277.

Hallmann, K., Zehrer, A. ve Müller, S. (2015), Perceived Destination Image: An Image Model for a Winter Sports Destination and Its Effect on Intention to Revisit, Journal of Travel Research, 54 (1), 94 -106.

Hudson, S., Ritchie, B. ve Timur, S. (2004) Measuring Destination Competitiveness: An Empirical Study Of Canadian Ski Resorts, Tourism and Hospitality Planning \& Development, 1 (1), 79-94

İbragimov, M. (2001) Ürün Çeşitlendirmesi Açısından Kış Turizmi ve Almatı Çimbulak-Medeu Örneği. Dokuz Eylül Üniversitesi Sosyal Bilimler Enstitüsü Basılmamış Yüksek Lisans Tezi,İzmir.

İncekara, A. (1998). Doğu Anadolu'da Kış Turizmi ve Gelişme Olanakları. İstanbul: İstanbul Ticaret Odası Yayını.

Kämpf, R., Kaspar, W. (2005). Erfolgsfaktoren im alpinen Tourismus, BAK Basel Economics, seco Publikation Direktion für Standortförderung, IBC Report 2005, Basel.

Kılıçarslan, N. (2008). Spor Turizmi ve Uluslararası Spor Organizasyonlarının Turizme Etkisi: 2011 Erzurum Üniversite Kış Oyunları. Yayınlanmamış Uzmanlık Tezi, Kültür ve Turizm Bakanlığı Tanıtma Genel Müdürlüğü, Ankara.

Koşan, A. (1996). "Kış Turizmi” Tourism and Hotel Trends. Bahar 1996. Bilkent University. Ankara.

Lim, C. (1997). Review of international tourism demand models, Annals of Tourism Research, 24(4), 835-849.

Merriam, S. B. (2013). Nitel Araştırma: Desen Ve Uygulama İçin Bir Rehber. (Çev: S. Turan). Ankara: Nobel Yayınevi.

Priporas, V. C., Vassiliadis, C. A., ve Stylos, N. D. (2012). Qualitative Findings On Marketing Management Practices From Greek Ski Centers, Qualitative Market Research An International Journal, 15 (4), 385 403

Şebin, K. (2009). Erzurum Kış Sporları Turizmi İle İlgili Yöre Halkının Tutum ve Beklentileri. Marmara Üniversitesi, Să̆lık Bilimleri Enstitüsü, Yayınlanmamış Doktora Tezi, İstanbul.

Türkeri, İ. (2014). Destinasyon Aidiyeti Oluşturulmasında Destinasyon İmajının ve Kişiliğinin Rolü: Kış Turizmi Örneği (Palandöken Kayak Merkezi). Atatürk Üniversitesi, Sosyal Bilimler Enstitüsü, Turizm İsletmeciliği ve Otelcilik Anabilim Dall, Yüksek Lisans Tezi, Erzurum.

Urry, J. (1987). Some Social and Spatial Aspects of Services. Society and Space , 5, 5-26.

Ülker, İ. (1992). Dağ Turizmi: Planlama Yöntemleri, Yüksek Dağlarımız, Kayak Merkezleri Ankara: T. C. Turizm Bakanlığı.

Yılmaz, M. K., Başar, E. E. ve Pabuççu, H. (2015). Pazarlama Kaynaklarına En Uygun Rekabetçi Pazarlama Stratejisinin Belirlenmesi: Kış Turizmi Otellerine Yönelik Bir Uygulama, Ege Akademik Bakış, 15 (3), 409-419.

Çambaşı Doğa Tesisleri: (http://cambasidoga.com/merak-edilenler), Erişim Tarihi: (12.01.2020).

Ordu İl Kültür ve Turizm Müdürlüğü, Çambaşı Yaylası ve Çambaşı Kayak Merkezi: (https://ordu.ktb.gov.tr/TR130415/cambasi-yaylasi---cambasi-kayak-merkezi.html), Erişim Tarihi: (22.12.2018). 